University at Buffalo School of Law

Digital Commons @ University at Buffalo School of Law

\title{
Beyond Juba: Does Uganda Need a National Truth and Reconciliation Process?
}

\author{
Makau Mutua \\ University at Buffalo School of Law
}

Follow this and additional works at: https://digitalcommons.law.buffalo.edu/journal_articles

Part of the Human Rights Law Commons

\section{Recommended Citation}

Makau Mutua, Beyond Juba: Does Uganda Need a National Truth and Reconciliation Process?, 13 Buff. Hum. Rts. L. Rev. 19 (2007).

Available at: https://digitalcommons.law.buffalo.edu/journal_articles/563

\section{C) ${ }_{\text {COPYRIGHT }}^{\text {N }}$}

This Article is brought to you for free and open access by the Faculty Scholarship at Digital Commons @ University at Buffalo School of Law. It has been accepted for inclusion in Journal Articles by an authorized administrator of Digital Commons @ University at Buffalo School of Law. For more information, please contact lawscholar@buffalo.edu. 


\title{
BEYOND JUBA: DOES UGANDA NEED \\ A NATIONAL TRUTH AND RECONCILIATION PROCESS?
}

\author{
Makau Mutua*
}

Virtually every African state, and Uganda is not an exception, is a product of the rape of the continent by imperial European powers. ${ }^{1}$ It is that original sin - the illegitimate conception - that has been the bane of the African state. It is true that Africans cannot, and should not, blame every ill on colonialism and the nearly fatal trauma it inflicted on Africans. But any honest intellectual excavation of the African condition cannot but locate its pathologies in imperial conquest and its debilitating consequences. This is not to say that the African political class has not through its unfathomable bankruptcy done its part to sink the continent. From mighty Nigeria to pathetic Chad to the comic tragedy that has become the regime of President Mwai Kibaki in Kenya, one cannot but wonder how far Africa will fall before it rises up again. Yet, we cannot despair. We must plant and nurture the seeds of that renaissance that our people so desperately need and deserve. For beautiful Uganda, the genesis of that recovery may lie in Juba. But it most certainly can only be realized by looking beyond Juba.

The challenges of African statehood constitute much of the literature on the post-colonial African state. ${ }^{2}$ Soon after the Decade of Independence - the 1960s - the short burst of enthusiasm was replaced by a long, almost unremitting, period of despair. In Uganda, military coups, civil wars, repressive regimes, refugee flows, and economic stagnation soon came to define the state. Uganda, like many post-colonial states, retained

\footnotetext{
* SUNY Distinguished Professor, Professor of Law, and the Director of the Human Rights Center at State University of New York at Buffalo School of Law; Chairman, Kenya Human Rights Commission. The following address was made at Makerere University, Kampala, Uganda, December 1-2, 2006. It was entitled Beyond Juba: Building Consensus on a Sustainable Peace Process for Uganda.

1 Crawford Young, The Heritage of Colonialism, in Africa In World Politics 19 (John W. Harbeson \& Donald Rothchild, eds., 1991).

2 See, e.g. Crawford Young, Ideology and Devlopment in Africa (1982); Collapsed States: The Disintegration and Restoration of Legitimate Authority (I. William Zartman, ed., 1995); State, Conflict, and Democracy IN Africa (Richard Joseph, ed., 1999); Civil Society and State in Africa (John Harbeson, Donald Rothchild, \& Naomi Chazan, eds., 1994); Michael Bratton \& Nicholas Van de Walle, Democratic Experiments in Africa (1997); Robert Fatton, JR., Predatory Rule: State and Civil Society in Africa (1992); AfRICA IN World Politics (John W. Harbeson \& Donald Rothchild, eds., 1991).
} 
international legitimacy and its juridical status in legal, normative terms, although there was no doubt that its empirical, domestic writ was wafer thin. ${ }^{3}$ It is remarkable the country did not collapse altogether given the acuteness of internal illegitimacy. It is a miracle that the ravages of Milton Obote and Idi Amin - not to mention some short-term brutes in between did not completely terminate the Ugandan state as we know it. Sadly, President Yoweri President Museveni, once hailed as a savior, has turned into a villain, and now threatens to join the list of his disgraced and departed predecessors.

There is no denying the obvious. Uganda has been engulfed in civil war for most of its post-colonial existence. After the 1986 Museveni takeover of the state - a regime change that was hailed across the globe - there was an undeniable opportunity for the political class to cultivate a new consensus and a social contract between the state and the people. At first, President Museveni appeared to listen. The elites and the intelligentsia welcomed him as he restored law and order and embarked on a project of state reconstruction. Even a truth commission, known as the Commission of Inquiry into the Violation of Human Rights, was established to uncover the truth and chart a path to national healing. ${ }^{4}$ But its mandate was too vacuous, legalistic, and narrow. Besides, it lacked the political will, resources, and imagination to make a break with the past. It was virtually irrelevant by the time it produced its voluminous report in 1994. In any case, President Museveni, once considered an idealist, had been corrupted by power. By all accounts, he had lost the zest to reform the state and reconstitute its power. In 1995, President Museveni instituted an illiberal constitution under which his exotic "Movement System" banned political competition and assured his continuation in power. But in 2005, he bowed to domestic and international pressure to permit open political activity and multipartyism, although he retained all levers on power. In the face of stiff opposition, he amended the constitution to remove term limits so that he could be returned to power, which he was in March 2006.

The point is that beyond the first few years of his rule when he feigned reform, President Museveni soon became a typical post-colonial despot. Even in this, he was out of touch with the rest of Africa, most of whose leaders had acquiesced to some form of political competition. As a result, today he sticks out like a sore thumb in a continent once dotted by one-party states and Strong Men. The result of the political dictatorship that

3 Robert H. Jackson \& Carl G. Rosberg, Why Africa's Weak States Persist. 35 WORLd Politics 1, 5 (1982).

4 Recommendations by the Uganda Commission of Inquiry into the Violation of Human Rights, 3 East Afr. J. OF Hum. RTs. 140 (1997). 
President Museveni has established is a country that has failed to cohere into a nation. In the north, a civil war that is now more than two decades old continues to ravage the people. The key protagonists in the war - the barbaric Lord's Resistance Army and the Uganda People's Defense Force have pursued a scotched earth policy although it is clear that there cannot be a military solution to the conflict. In the aftermath, tens of thousands have been slaughtered and maimed, and millions displaced. The enormity of the atrocities committed in that conflict haunt the human conscience. Elsewhere in Uganda, over twenty civil wars and conflicts have raged in the past two decades alone.

Two decades into his reign - for that is what it is - there is little doubt that the Museveni state lacks the basic political legitimacy and will to create a united, viable, and democratic state. It is more than clear, given the multiple challenges to his regime over the years, that he does not command the loyalties of vast segments of the population. Under these circumstances, what is to be done? I believe that Uganda will not recover as a state if it does not confront the demons that have tormented it for decades. First, Uganda must have the courage to objectively and without fear or favor identify those demons. But the process for the identification of those demons must be national, inclusive, transformational, and cathartic. Secondly, although the Museveni government must facilitate this process, it cannot own or control it. An independent and truly representative body of all stakeholders must be empanelled to define and lead the process of national recovery. Thirdly, the process of unveiling the pathologies that have crippled society must be open and participatory. It must include especially those who have been aggrieved, no matter the nature, seriousness, or severity of their grievances.

The history of Uganda has been brutal, and the perpetrators of human rights atrocities may be as many as their victims. That is why for a truly national truth and reconciliation process, no one can be left out. But this process will not succeed unless it results in some measure of justice even retributive justice. In this regard, the Uganda Amnesty Commission and the law under which it is established must be scrutinized afresh to determine if they can be a useful and organic part of the process of national recovery. Blanket amnesties or isolated and incoherent peace accords with disparate factions and rebel groups will do nothing to transform the ship of state unless they are part and parcel of a comprehensive national truth and reconciliation process.

\section{Reform and Political Transformation}

The political convulsions of the 1990s irrevocably altered the political cultures of most African states. The protest coalitions of oppositionists, 
professionals, students, the press, and trade unions left an indelible mark on the African state. They forced long-serving autocrats to either relinquish power through open elections, overthrew them outright, or loosened the grip of the state over society through piece-meal reforms. Virtually no state was left untouched by the wave of change dubbed by many Africans the second liberation, suggesting an epochal shift of the magnitude of decolonization. Crawford Young identifies Libya and Sudan as the only holdouts, but even the latter acquiesced to "token gestures of liberalization." 5 With a few exceptions, gone were the big men who bestrode the African state like a colossus. President Museveni's clever arguments in favor of the Movement System and no-party democracy seemed to defy these pressures. The West, of whom he became a darling, shielded him from domestic challenges to open up the political system. It is this collusion between the West and his regime that retarded the recovery of the state.

Admittedly, many of these reformist changes in Africa have yielded mixed results, and one needs only look at next door in Kenya to see why. Even so, many of these political transformations have ushered the project of democratization, not matter how uneven and wobbly. At the core of these reforms is one thing: the struggle over the nature of the state. At the center of that question is how state power is organized, shared, and exercised. In other words, the constitution of the state - the sum total of its powers - lies at the center of the crises of the modern African state. That is why the most urgent question for reformers should revolve around the constitution as a document of values, objectives, and principles. Clearly, rewriting the constitution by itself will not suffice to cure the African malaise. But it is the essential starting point for political transformation and the reclamation of the state. For without a redefinition of the meaning and the purpose of the state - and its relationship to individuals and groups in society - the political culture cannot be transformed for the better. But the constitution is just one of the many variables that the reconfiguration of state power in Africa must address. The nature and origin of the African state - and its relationship with the international legal, political, and economic orders - must be part of the package of reforms to bring the continent out of its abyss.

The focus of this speech is the struggle to reform the Ugandan state through a new compact born of a national truth and reconciliation process. That process, which must involve at some level the work of the International Criminal Court and the Juba talks, must be holistic. But Uganda, like other African states, suffers from a script of normative and structural deficits that ostensibly defy fundamental reforms. These weaknesses of the Af-

5 Crawford Young. The Third Wave of Democratization in Africa: Ambiguities and Contradictions, in State, Conflict, and Democracy in Africa, 15. 
rican state are largely responsible for the failure of the democratic project. The question is whether Uganda can recognize these common vault lines and heal them in a way that responds to the needs of its population. In other words, what overarching themes or questions must be addressed in the reform of the African state, and Uganda, in particular? How can these themes be applied to tackle the problem of the viability of the Ugandan state? In the sections below, I identify and discuss those variables.

The crisis of the Ugandan state is an inability to create a viable, legitimate, and democratic society. Virtually every major thinker and political scientist concerned with Africa has identified this problem as the bane of the African state. Simply put, the Ugandan state suffers from a deficit of democracy. But this begs the question - why is there a deficit of democracy? Political democracy, as a normative and structural ideology, arises from liberalism. Liberalism, in turn, is distinguished from other traditions by its commitment to formal autonomy and abstract equality. In its contemporary expression, liberalism requires a constitutional state with limited powers. Such a state would be anchored in a political democracy under the genus of a system known as constitutionalism. Today, many of these values have been captured in the human rights corpus, a collection of norms and practices that bind the state to limited, prescribed conduct. ${ }^{6}$

One of the roots of liberal theory has been its attention to the risk of the abuse of the individual by the state. Hence the skepticism of liberal theorists about entrusting the state with power that is not subject to enforceable limitations. Translated into political terms, constitutionalism then requires a system of government with several incontestable features, albeit in varying configurations. The state must be based on a conception of popular sovereignty in which the constitution assures that the state is accountable to the people through a range of devices and techniques, the most critical of which is open, periodic, multiparty elections. ${ }^{7}$ But the powers of the state would be curtailed through the system of checks and balances and the separation of the three arms of the state to ensure an independent judiciary. In this scheme, the judiciary is the guardian of legality and of the rule of law to safeguard individual rights through the judicial review of executive action. Otherwise, the executive or the legislature could run amok and impose tyrannical rule on the populace. But constitutionalism is not just a set of rules, procedures, devices, and techniques. To become meaningful, constitutionalism must empirically become a set of cultural norms and values subscribed to by officialdom and the public at large at their core. It must be

6 Louis Henkin, The Age of Rights (1990).

7 Henry J. Steiner \& Philip Alston, International Human Rights in Context: Law, Politics, Morals 990 (2000). 
part of their zeitgeist. Uganda lacks almost all these basic rudiments for democracy.

In emergent societies, as is the case in Uganda, democracy cannot be merely a matter of procedures and rules. Democratic rule must be viewed as substantive, meaning that procedures and rules must have just and legitimate outcomes in the eyes of the populace. That is why the 2006 presidential elections in Uganda failed this test. In such a case, the experiment in open government will fail. That is why Schumpeter ${ }^{8}$ and Huntington, ${ }^{9}$ whose definitions of democracy are predominantly procedural, may not completely speak for the African condition. For Africa, democracy cannot simply be a method; it must pay particular attention to outcomes. Otherwise, the state will not incubate in the people allegiance to it. Furthermore, outsider groups and interests will foreswear the state and deny it legitimacy. Although as Dahl suggests open elections are the critical difference in a democracy, the formal right to vote and stand for elections can be meaningless as an abstract rule if substantive conditions do not exist to permit real choices and minimize barriers to participation. ${ }^{10}$ Even though democracy is the single most important deficit in Uganda - and the critical proxy for the legitimization of the state - it would be a mistake to treat it simply as a method of governance.

Scholars have therefore put forward several thematic categories that should be addressed in the recovery of the African state. There is neither unanimity on the number of categories nor on the emphasis to be placed on each. What is not in doubt, however, is the salience of each of the categories. Needless to say, the categories revolve around the viability and legitimacy of the state. One of the most important, and perhaps the only category on which there is universal agreement among the scholars of African politics, is democratization. Democratization is a recurrent theme in the work of every scholar on African politics. ${ }^{11}$ The subject appears in variety of guises

8 J. Schumpeter, Capitalism, Socialism, and Democracy (1950).

9 Samuel Huntington, The Third Wave: Democratization in the late Twentieth Century 6 (1991).

10 R. Dahl, A Preface to Democratic Theory 14, 71 (1956).

11 See, e.g., Constitutionalism in Africa: Creating Opportunities, Facing Challenges (J. Oloka-Onyango, ed., 2001); Willy Mutunga, ConstrtutionMaking from the Middle: Civil Society and Transition Politics in Kenya, 1992-1997 (1999); Economic Change and Political Liberalization in SubSaharan Africa (Jennifer Widner, ed., 1994); Democracy in Africa: The Hard Road Ahead (Marina Ottaway, ed., 1997); Richard Joseph, The Democratic Challenge in Africa (1995); Democracy in Developing Countries: Africa (Larry Diamond, A. Kirk-Greene, \& O. Oyediran, eds., 1988); Beyond CAPITAL- 
- as governance, electoral politics, and political participation, among others. Richard Joseph refers to this phenomenon as the reconstitution of political order. ${ }^{12}$ Indeed, this is an exercise that requires a fundamental reconstruction of the state beyond the traditional panacea of multiparty elections, strengthening legislatures, or revitalizing political parties. But the state cannot be reconstructed without a new constitutional dispensation. That is why a new democratic constitution - one that is popularly mandated - must be written. In this regard, Uganda must go back to the drawing board and rework its constitutional dispensation to endow it with popular legitimacy.

The other key theme involves the centrality of civil society in the reconstruction and democratization of the Ugandan state. It is not the purpose here to explore in any depth the conceptual meanings and definitions of civil society from John Locke or Georg Hegel and their theory of the social contract. ${ }^{13}$ Patrick Chabal has defined civil society as a "vast ensemble of constantly changing groups and individuals whose only common ground is their being outside the state and who have. . acquired some consciousness of their externality and opposition to the state." $1+$ As Young correctly notes, given this definition, civil societies pre-dated the imposition of the colonial state by Europeans..$^{15}$ In any case, the modern state, including its post-colonial variant, is deemed incapable of self-restraint without a vigilant and vibrant civil society. ${ }^{16}$ Thus civil society is an indispensable element in the push for democratization. An analysis of any political transi-

ism ANd Socialism in Kenya and Tanzania (Joel D. Barkan, ed., 1994); Michael Bratton \& Nicholas van de Walle, Democratic Experiments in Africa: Regime Transitions in Comparative Perspective (1997); Claude Ake, Democracy and Development In Africa (1996); Claude Ake, Rethinking African Democracy, 2 Journal of Democracy 32 (1991).

12 Joseph, State, Conflict, and Democracy in Africa, supra note 2, at 3.

13 John Locke, Two Treatises of Civil Government (Aldine Press 1955) (1960); The State and Civil Society: Studies in Hegel's Political Philosophy (Z.A. Pelczynski ed., 1984); Civil Society and the State: New European Perspectives (John Keane ed , 1988).

14 Patrick Chabal, Introduction, in Political Domination in Africa 15 (1986).

15 Crawford Young, The African Colonial State in Comparative PerspecTIVE 222 (1994).

16 Civil Society and the State in Africa (John W. Harbeson, Donald Rothchild, \& Naomi Chazan, eds., 1994); Michael Bratton \& Nicholas Van DE Walle, Democratic Experiments in Africa, supra note 11, at 147-149. 
tion must of necessity pay particular attention to the structure, role, composition, size and depth, and philosophy that drive civil society.

A critically important variable in the reformation of the Ugandan state is the relationship between state power and ethnic groups that constitute the whole. The failure, and tragic collapse, of a number of Ugandan regimes has been occasioned by their inability to accommodate pre-colonial group identities and forge a common national psyche and destiny. The collapse of the regimes of Obote I and II was largely attributable to the failure of the state to devise a system of government that could adequately provide for the fruitful co-existence of its contending nationalities. In legal constitutional terms, this is deceptively a problem of balancing group rights with the interests of the central state. Yet the calculus is more complex. It is more about forging a national character by absorbing pre-colonial identities into the whole without establishing an informal hierarchy of ethnicities. To be sure, this may include systems of devolution at the local level, but within a unifying, accommodating, and inclusive central authority.

Political parties occupy a central place in the governance of the modern state. But in Uganda, this has not been the case ever since the regime of Idi Amin. Political parties have been suppressed although their consciousness could never be eradicated. President Museveni largely muted the wave of political liberalization that swept through Africa in the 1990s, although the embers of multipartyism remained very much alive. But Ugandan political parties have not per se been a force for democratization. Ugandan political parties are not generally guided by ideological considerations and rarely, if at all, mobilize their members on the basis of coherent policies. Regrettably, parties in Uganda and other parts of Africa are either empty receptacles for ethnic barons or have no deep resonance in the population. As a result, the ability of political parties to deepen and incubate democratic discourse is sharply limited. Even so, the project of democracy requires competent and ideologically sound political parties. That is why this is not an argument against political parties. Nor should a single godfather exclude Ugandan political parties from the politics by virtue of this argument. The state simply has to create a constitutional and legislative framework to govern political parties so that they can be driven by ideology, become internally democratic, mainstream gender, and assume a national identity. The maturation of political parties is a continuous process, not an event.

Last, but not least, is the tendency of messianic religions - Islam and Christianity - to either be a flashpoint of conflict or retard political discourse because of strict and textualist interpretations of religious doctrines and texts. In several cases, religious and sectarian conflict has been a source of instability and dysfunction in the state. Among other factors, re- 
ligious conflicts and intolerance have been responsible for the inability of the state to become viable and democratic. They have made it extremely difficult to tame political power and have wrecked havoc with institution building. Even when not engaged in conflict with others, Islam and Christianity have tended to advocate public positions that either undermine or restrict the rights of women and girls. Again, in the case of Uganda, this has been largely with respect to "hot-button" social questions, such as gender equality, family law, property ownership and inheritance, and privacy in the law and constitution making processes. ${ }^{17}$ The potential for the use of religion to entrench the subordination of women - and hence the retardation of the democratic project - in the patriarchal Ugandan state cannot be overstated.

\section{Unpacking the Truth and Reconciliation Process}

But the reformist project that I sketch for Uganda in this speech will not happen without deliberate orchestration. That is why the Juba talks offer a unique moment to nationalize a truth, peace, justice, and reconciliation process. Truth and national reconciliation processes are relatively new institutional vehicles in the universe of law and justice. As an institution of transitional justice, such processes are just over two decades old. ${ }^{18}$ The centerpiece of such a process has usually been a truth commission. Each country where it has been established - starting in Argentina and later in Uganda, South Africa, El Salvador, Chile, Argentina, Peru, Ghana, Sierra Leone, among others - has had to improvise and craft an institution that was determined by the particular country's traumatic history and the balance of the political forces. That is why there is no model truth commission or peace process anywhere that Uganda can simply mimic or copy. But Uganda, having had a truth commission already, needs to look beyond such an institution and think about a holistic approach to peace and reconciliation. In any case, even if a truth commission were to be established, it would have to go beyond the narrow confines of the Uganda Commission of Inquiry into the Violations of Human Rights. Even so, Uganda should learn from the experiences of other countries, and decide the type of peace and reconciliation process it should explore. It is my view that Uganda should address its past and present crises with the institution of a truth and reconciliation process that is guided by a truth commission, but with a wide

17 Sylvia Tamale, When Hens Begin to Crow: Gender and Parliamentary Politics in Uganda (1999).

18 Martha Minow, The Work of Re-Membering: After Genocide and Mass Atrocity, 23 Fordham Int'l L. J. 429 (1999); Priscilla B. Heyner, Unspeakable Truths: Confronting State Terror and Atrocity 10 (2001). 
mandate to reconstruct the state. This must include addressing the variables of reconstituting political order, rewriting the constitution, and developing a national framework in which civil society and political parties can become the central engines of democratization. It is in this context that the ethnicization of politics and the use of religion to retard democracy can be addressed. That is the only route by which current abominations, such the genocidal conflict waged by both the LRA and the government in the north, can be permanently terminated.

The truth commission is now an internationally familiar conception and institution for a state emerging from a period of gross human rights abuses and abominable economic crimes and debating how to address them. The term truth commission serves as the generic designation of a type of national organ and process that is intended to construct a record of this tragic and barbaric history. Thus truth commissions offer countries ways of responding to years of bare-knuckled barbarism run rampant, of horrific human rights violations that took place for political, ethnic, religious, tribal, economic, class, ideological, gender, and other conflicts over justice, power, and the control of economic resources. Truth commissions may be an alternative to other national responses to these abuses and societal dysfunctions. At the one extreme, these responses could include criminal prosecutions. On the other, the granting of some form of amnesty to the perpetrators. Truth commissions are established for gross human rights violations that normal adjudicatory process cannot, are unwilling, or unable, to address. ${ }^{19}$

Truth commissions are created principally at the time of a state's transition toward a more democratic or participatory government, a government that espouses the ideals of democracy, of power bounded by law, of formal legal equality, and social justice. It matters not how the moment of political change occurred - it could have been violent or non-violent. What matters is that there is a normative and substantive departure by the government or state from its predecessor or previous policies and attitudes. Thus it could be change from autocracy to democracy, from opacity to transparency, from open shameless graft to fiscal and economic accountability. But that change must be structural, ideological, and fundamental, it cannot be a continuation of the same. The change must signal real and genuine regime transformation. The question for Uganda is whether that moment of transition is at hand. Does the Museveni state seek and understand the necessity of a lasting solution to the problems of legitimacy that have bedeviled it since 1986? Is the state willing to enter a new compact no just with

19 Republic of Kenya, Report of the Task Force on the Establishment of a Truth, Justice, and Reconciliation Commission (2003). 
the north or the LRA, but with all its citizens? In a word, is the state ready to embrace genuine democracy?

National truth and reconciliation processes can serve multiple objectives, which are all interrelated. They can act as a sort of a national catharsis in which the country goes through a deep and penetrating process of cleansing the past. ${ }^{20}$ This function is akin to therapy. It can perform the function of moral reconstruction, in which a country takes stock of its morality in politics, governance, cultural values, and its view of humanity. Moral reconstruction implies learning lessons from the past and revising the nation's moral code. It could be a vehicle for reconciliation after truth and justice have been told and done. Here, society must pass judgment on what it has heard; it must, in effect, establish a moral account of the historical record. This process of introspection is deeply political, although it is also moral. It is political because it requires the nation - both victim and perpetrator alike - to know, understand, and acknowledge the moral wrongs that were committed, and why. Without this basic acknowledgement, there can be no genuine movement to a cleaner and more just future. The nation must, as it were, submit itself to the moral truth about its past, no matter how abominable.

Another function, which is probably the most important one, is that of truth telling, where the perpetrators bare all, and the victims recount the horrors visited upon them by the sadism of either the state or non-state actors. In Uganda, there is no doubt that the state has done its share of abominations. But non-state actors, including the Museveni rebel forces when they were fighting to capture the state, have been equally brutal and barbaric. Take for example, the unspeakable evils committed by Joseph Kony's so-called Lord's Resistance Army. Its brutalities are so shocking that just reading accounts of them is simply sickening. ${ }^{21}$ The most vulnerable victims have been women and girls, who have been subjected to indescribable crimes. Justice at the international level is so rare in such atrocities that credible domestic processes are indispensable. ${ }^{22}$ Domestic truth and reconciliation processes might yield several options: a society may choose to forget or ignore the truth, gloss over it, or use it to sanction the perpetrators and deploy it for the moral and political reconstruction of the state. Some truth commission processes seek the truth, others justice or reconciliation, and some all three. Most truth commissions are victim-cen-

20 See Desmond Tutu, No Future Without Forgiveness (2000).

21 See Jeffrey Gettleman, Uganda Peace Hinges on Amnesty for Brutality, N.Y. Times, Sept. 15, 2006, at A1.

22 See Betty Murungi, Prosecuting Gender Crimes at the International Criminal Tribunal for Rwanda, AFR. LEGAL AID Q (April-June 2001). 
tered. In Uganda, the process must combine truth telling with justice and national reconciliation.

In terms of the implementation of the national truth and reconciliation process, whose focal point is usually a truth commission, there must inclusivity and open participation. In this respect, the proceedings must be carried live on radio and television countrywide. The commission must have the power to summon and subpoena and require any person to appear before it and completely submit to its instructions or be held in contempt and jailed. It must facilitate, and where necessary initiate or coordinate inquiries into: gross violations of human rights and economic crimes (perhaps these should be separate), including violations which were part of a systematic nature; the nature, causes, and extent of gross violations of human rights and economic crimes, including the antecedents, circumstances, factors, context, motives and perspectives that led to the violations; the identity of all persons, authorities, institutions, and organizations involved in such violations; and establish whether the violations were the result of deliberate planning on the part of the state or any of its organs, or any political organization, official, or individual. No perpetrators - be they non-state actors or government officials - can be shielded from the open process. Nor should any blanket amnesties be given to buy peace. That is a recipe for the continuation of impunity. The Uganda amnesty law violates a cardinal principle of the struggle against impunity. ${ }^{23}$ That is why the indictment of the LRA Five by the ICC cannot be vacated for the sake of appeasing a monster. It would buy a false peace and render the whole process of transitional justice meaningless.

Truth and reconciliation processes must have justice as their core function. They must establish accountability, both political, moral, and legal for the violations; facilitate, initiate, gather, and coordinate the collection of information and evidence from any person, including victims, which establishes the identity of the victims of such violations, and their perpetrators; establish the fate and status of victims, and the extent of harm, suffering, or loss incurred by them; determine what compensation, reparations, and restitution should be awarded to victims, their families, and survivors; order the dismissal and barring from public service or politics of particular perpetrators; order the seizure, forfeiture, and surrender of illegally acquired property and other material goods, including money and other fiscal instruments; and make mandatory referrals to the responsible institutions created to sanction and prosecute those who are deemed eligible for punishment. The final report of the process must be made public in full. It must

23 See Human Rights Watch, Uganda: No Amnesty for Atrocities, July 28, 2006, available at http://hrw.org/english/docs/2006/07/27/uganda13863.htm. 
decide if a limited number of amnesties with qualified immunity ought to be granted to further the ends of national reconciliation. The process should not last for more than two years because it would sap national energy and be the subject of sabotage by detractors and perpetrators.

There are two possible routes for the establishment of a national truth and reconciliation process. Its central organ, such as a truth commission, could to be established either as an independent organ by an act of parliament or through a presidential order under the powers granted him by the Constitution. In either case, the truth commission must not be subject to direction or dictation from any official or arm of government. For obvious reasons, the legitimacy and independence of the process must be beyond reproach. All the members who direct and conduct the process must be chosen for their probity, expertise, and outstanding morality. Effective truth commissions are not large. They must be drawn from among the widest cross-section of Ugandans. The commission should include several nonnationals known for their competence, fairness, and expertise. This would act to check the partiality of nationals and bring in comparative experiences. It may also inspire confidence in non-state actors who may feel that justice is not possible from a purely national panel.

\section{Connecting Juba to National Reconstruction}

In this speech, I have attempted to advocate something broader and more encompassing than a simple truth commission, although I believe that such an institution ought to be an important part of the project of national recovery for Uganda. I do not believe that the Uganda Commission of Inquiry into the Violation of Human Rights served its purpose. But in the context of the contemporary situation, I believe that it would be foolhardy to think about instituting a garden-variety truth commission. The reason is that Uganda is beset by two separate, but interrelated, challenges. Both have their bases in the illegitimacy of the Museveni regime. The first comes from elements within civil society and the political parties who believe that the state is undemocratic and illiberal. These sectors, which seek a democratic renewal of the state through constitutional means, believe that President Museveni is a major stumbling block to democratization. The second challenge is posed by armed non-state actors, the most prominent of which the LRA, which is irredentist in nature, although its exact political project remains a mystery. Both challenges raise questions of self-determination. The good news is that the Juba talks provide an opening through which a process to comprehensively address both problems could be launched.

However, it is not lost on anyone that national reconstruction and reconciliation are not possible without truth and justice. It is also clear that a reconciliation process - with Kony's LRA in particular - must not be 


\section{BUFFALO HUMAN RIGHTS LAW REVIEW Vol. 13}

achieved by forgiving the perpetrators and forgetting the victims. ${ }^{24}$ Such an expedient, unprincipled outcome would simply entrench impunity and strengthen the imperial and undemocratic state that President Museveni has constructed over the last two decades. There is little doubt that an isolated pact with the LRA would make President Museveni even more contemptuous of the democratic reformers who seek change by civil means and processes. That is why every attempt must be made to link Juba to a comprehensive reform of the state. The institution that would spearhead the reform and peace process - a truth commission with a broad mandate cannot be a witch-hunt or a whitewash. It cannot be selective or target any particular community.

Those who do not learn from the mistakes of history are bound to repeat them. A true democratic transition cannot simply overlook, blink at, or gloss over the gross human rights violations and economic crimes committed by state and non-state actors since Uganda's independence in 1962. It is only by fully confronting the past - and completely accounting for it can Ugandans create a legitimate basis for democratic development and economic renewal. Ugandans cannot simply forgive and forget the abominable crimes of the past. Nor should the victims of past abuses be expected to contemplate forgiveness without a full public accounting and unless justice has been done. But no one must forget because national amnesia for past abuses invites their recurrence. The pathologies of the Ugandan state, which now traumatize its people, cannot be swept under carpet. Only a broad, inclusive, and open national conversation can start the healing process.

Ultimately, the reform of the Ugandan state lies in the full-fledged democratization of political society. In this, civil society and political parties must play the leading role. President Museveni must understand that he will not live forever, and should therefore not conflate the fate of the Ugandan people and state with his personal political fortunes and future. Uganda is - and must be - greater than any single individual. That is the premise of modern statehood. That is why President Museveni must allow a national process of reconstruction to commence at once. He must not attempt to control or manipulate that process to his narrow political and partisan interests. After rescuing Uganda from the Amin and Obote death choke, President Museveni should now be concerned about the legacy that he will leave the country. Does he want to plunge it back into the abyss of yesteryear, or would he rather oversee the full democratization of the country? Whether he seizes the Juba talks as an opportunity to overhaul the state will determine his legacy.

24 Jeffrey Gettleman, UN Envoy Meets with Ugandan Rebel, N.Y. TrMEs, Nov. 13, 2006, at A3. 